\title{
ANALISIS BIAYA PENDAPATAN DAN R/C AGROINDUSTRI KERIPIK PISANG (Studi Kasus Pada Perajin Keripik Pisang Di Desa Parigi Kecamatan Parigi Kabupaten Pangandaran)
}

\author{
AYU AGUSTIN ${ }^{1 *}$, AGUS YUNIAWAN ISYANTO ${ }^{1}$, BUDI SETIA ${ }^{1}$ \\ ${ }^{1}$ Fakultas Pertanian, Universitas Galuh \\ *Email : aagustin368@gmail.com
}

\begin{abstract}
ABSTRAK
Penelitian ini bertujuan untuk mengetahui : 1) besarnya biaya agroindustri keripik pisang di Desa Parigi Kecamatan Parigi Kabupaten Pangandaran, (2) besarnya pendapatan agroindustri keripik pisang di Desa Parigi Kecamatan Parigi Kabupaten Pangandaran, dan (3) besarnya R/C agroindustri keripik pisang di Desa Parigi Kecamatan Parigi Kabupaten Pangandaran. Metode yang digunakan dalam penelitian ini adalah metode survei dengan mengambil kasus pada perajin keripik pisang di Desa Parigi Kecamatan Parigi Kabupaten Pangandaran. Data yang digunakan adalah data primer dan data sekunder. Sampling yang digunakan adalah metode sampling jenuh atau sensus sebanyak 5 orang. Hasil Penelitian menunjukkan bahwa : 1) Rata-rata besarnya biaya agroindustri keripik pisang di Desa Parigi Kecamatan Parigi Kabupaten Pangandaran dalam satu kali proses produksi adalah sebesar Rp. 1.673.890; rata-rata besarnya penerimaan agroindustri keripik pisang di Desa Parigi Kecamatan Parigi Kabupaten Pangadaran dalam satu kali proses produksi adalah sebesar Rp 1.723.000; rata-rata besarnya pendapatan agroindustri keripik pisang di Desa Parigi Kecamatan Parigi Kabupaten Pangandaran dalam satu kali proses produksi adalah sebesar Rp 85.110 dan rata-rata besarnya R/C agroindustri keripik pisang di Desa Parigi Kecamatan Parigi Kabupaten Pangandaran adalah sebesar 1,03 .
\end{abstract}

Kata Kunci: Biaya, Pendapatan, R/C

\section{PENDAHULUAN}

Menurut Masyuri (1994) dalam

Mokodongan, dkk (2017) peran pertanian

sangat besar pada ekonomi negara terutama dalam pertumbuhan yang berciri khas agraris seperti Indonesia. Bidang pertanian dan industri yang berbasis pertanian atau bisa disebut agroindustri menjadi fokus utama pembagunan ekonomi. Dalam agribussines system, agroindustri merupakan subsistem yang bersama subsistem lain membuat jaringan agribisnis. Sistem agribisnis yaitu; subsistem agroindustri hulu, usahatani (pertanian), agroindustri hilir, pemasaran dan penunjang. Sehingga pembangunan agribisnis yang menyeluruh tidak dapat terlepas dari Agroindustri, Pembangunan agroindustri akan menaikan hasil produksi, kenaikan harga hasil pengolahan, serta dapat menghasilkan nilai tambah hasil pertanian.

Menurut Palisuri agroindustri pada dasarnya mencakup kegiatan pengolahan yang sangat luas, baik dari tahapan jenisnya maupun dari prosesnya. Sehingga pengertian agroindustri yang dapat dijelaskan, sebagai suatu kegiatan industri yang memanfaatkan produk primer hasil pertanian untuk bahan baku dan diolah sedemikian rupa agar menjadi olahan baru, 
baik yang bersifat olahan mentah atau yang dapat segera dikonsumsi.

Departemen Pertanian (2005) dalam Angriani, dkk (2014) pisang adalah produk pertanian yang mudah rusak. Pisang merupakan komoditas unggulan yang memiliki potensi besar untuk produksi buah nasional. Potensi buah pisang cukup besar dalam distribusi pendapatan masyarakat petani, selain itu pisang juga menjadi bahan makanan olahan (untuk chip, keripik, puree, tepung) dan produk pertanian yang potensial untuk menaikan ekspor buah.

Menurut Nuryanti, dkk (2017) pisang adalah produk pertanian yang sering dijadikan bahan baku agroindustri. Pisang banyak mengandung karbohidrat, gula, protein, dan vitamin $\mathrm{C}$ yang kadarnya lebih tinggi dibandingkan dengan buah-buahan lainnya, namun buah pisang sifatnya tidak dapat bertahan lama. Untuk mencegah pembusukan maka dilakukan pengawetan dengan cara pengolahan. Salah satu olahan dari pisang adalah keripik pisang. Selain untuk menambah daya penyimpanan, keripik pisang juga meningkatkan harga jual dibanding dengan harga jual pisang segarnya.

\section{METODE PENELITIAN}

\section{Jenis Penelitian}

Penelitian yang digunakan dalam penelitian ini adalah studi kasus dengan mengambil kasus pada agroindutri keripik pisang di Desa Parigi Kecamatan Parigi Kabupaten Pangandaran.

\section{Teknik Penarikan Sampel}

Agroindustri keripik pisang berjumlah 5 unit dan seluruhnya diambil sebagai sampel penelitian. Menurut Puguh Suharso (38) dalam Putri (2017) metode sampling jenuh atau sensus adalah teknik penentuan sampel bila semua anggota populasi digunakan sebagai sampel.

\section{Rancangan Analisis Data}

Untuk menghitung besarnya biaya, pendapatan, dan $\mathrm{R} / \mathrm{C}$, digunakan alat analisis sebagai berikut :

Biaya agroindustri keripik pisang dihitung dengan menggunakan rumus menurut Suratiyah (2006) :

$$
\mathrm{TC}=\mathrm{TFC}+\mathrm{TVC}
$$

Dimana :

$\mathrm{TC}=$ Total Cost (biaya total)

$\mathrm{TFC}=$ Total Fixed Cost (biaya tetap total) $\mathrm{TVC}=$ Total Variable Cost (biaya variabel total)

Pendapatan dihitung dengan menggunakan rumus dari Suratiyah (2006)

Dimana :

$$
\Pi=\mathrm{TR}-\mathrm{TC}
$$

$\Pi=$ keuntungan $(\mathrm{Rp})$ 
$\operatorname{Tr}=$ total penerimaan $(\mathrm{Rp})$

$\mathrm{TC}=$ total biaya $(\mathrm{Rp})$

Penerimaan agroindustri keripik pisang dihitung dengan menggunakan rumus menurut Suratiyah (2006) :

Dimana :

$$
\mathrm{TR}=\mathrm{Py} . \mathrm{Y}
$$

$\mathrm{TR}=$ Total Penerimaan $(\mathrm{Rp})$

Py $\quad=$ Harga Produk $(R p)$

$\mathrm{Y}=$ Jumlah Produksi (Rp)

$\mathrm{R} / \mathrm{C}$ usaha agroindustri keripik pisang dihitung dengan menggunakan rumus menurut Suratiyah (2006) :

$$
\mathrm{R} / \mathrm{C}=\frac{\text { Total Penerimaan }}{\text { Total Biaya }}
$$

\section{Tempat dan Waktu Penelitian}

Penelitian ini dilaksanakan pada perajin agroindustri keripik pisang di Desa Parigi Kecamatan Parigi Kabupaten Pangandaran. Adapun waktu penelitian dilaksanakan dengan melalui tahapan persiapan yaitu :

1. Survei awal, penyusunan Usulan Penelitian, dan Seminar Usulan Penelitian pada bulan April 2019.

2. Pelaksanaan penelitian yaitu pengumpulan data dan informasi dilakukan bulan Mei 2019.

3. Pengolahan data dan penulisan hasil penelitian dilaksanakan pada bulan Mei 2019 sampai dengan selesai.

\section{HASIL DAN PEMBAHASAN}

\section{Identitas Responden}

\section{Umur responden}

Umur merupakan faktor yang dapat mempengaruhi kemampuan seseorang dalam bekerja. Sebagian besar responden masih tergolong kedalam usia produktif, yaitu usia 45-50 tahun sehingga mempunyai tingkat kemampuan yang memungkinkan untuk menjalankan usahanya.

\section{Pendidikan responden}

Lama pendidikan formal responden yaitu 6 tahun atau lulusan Sekolah Dasar (SD). Responden mampu melaksanakan sekolah 6 tahun sehingga diperkirakan terhindar dari permasalahan buta hurup.

\section{Jumlah Tanggungan Keluarga} Responden

Tanggungan keluarga dalam penelitian ini adalah banyaknya jumlah anggota keluarga yang menjadi tanggungan responden untuk memenuhi kebutuhan hidupnya. Pada umumnya responden memiliki tanggungan keluarga 3-4 orang.

\section{Pengalaman Usaha Responden}

Pengalaman responden dalam mengusahakan keripik pisang yaitu 19 tahun. Bisa diketahui bahwa responden 
sudah sangat berpengalaman dalam menjalankan usahanya. Pengalaman berusaha akan mempengaruhi dalam menjalankan usahanya seperti menyikapi permasalahan dan mengambil keputusan dalam proses produksi keripik pisang

\section{Analisis Usaha}

Biaya yang dihitung dalam proses produksi keripik pisang selama satu kali proses produksi terdiri dari biaya tetap dan biaya variabel. Biaya tetap meliputi biaya penyusutan alat, pajak bumi dan bangunan, serta bunga modal, sedangkan biaya variabel yang dikeluarkan oleh perajin keripik pisang adalah terdiri dari biaya bahan baku dan bahan penolong. Untuk lebih jelasnya mengenai analisis usaha dapat dilihat pada tabel .

\begin{tabular}{|c|c|c|}
\hline h & $\begin{array}{l}\text { l. } 1 \text { Analisi Biaya } \\
\text { Pendapatan } \\
\text { Keripik Pisang }\end{array}$ & $\begin{array}{l}\text { Penerimaan, } \\
\text { Agroindustri }\end{array}$ \\
\hline No & Biaya & $\begin{array}{c}\text { Jumlah } \\
\text { (Rupiah) }\end{array}$ \\
\hline 1 & Biaya Tetap & $1,038,000$ \\
\hline \multirow[t]{2}{*}{2} & Biaya Variabel & 635,890 \\
\hline & Jumlah & $1,673,890$ \\
\hline 1 & Penerimaan & $1,723,000$ \\
\hline 2 & Biaya Total & $1,673,890$ \\
\hline 3 & Pendapatan & 85,110 \\
\hline
\end{tabular}

Tabel tersebut menunjukkan bahwa jumlah biaya tetap total agroindustri keripik pisang per satu kali proses produksi adalah Rp.1.038.000, sedangkan untuk biaya variabel total agroindustri keripik pisang persatu kali proses produksi adalah Rp. 635.890

Penerimaan adalah produksi total dikalikan dengan harga jual produk dan dinilai dalam rupiah per satu kali proses produksi. Tiap-tiap produsen kripik pisang memiliki penerimaan yang berbeda-beda. Perbedaan ini disebabkan kapasitas produksi yang berbeda. Penerimaan keripik pisang sebesar Rp. 1.723 .000 dengan kapasitas produksi sebanyak 201 $\mathrm{kg}$ dalam satu kali produksi.

Pendapatan atau keuntungan yang akan didapat setelah mengetahui nilai biaya dan nilai penerimaan. Semua pemilik usaha keripik pisang memiliki pendapatan bernilai positif (untung). Total pendapatan pada usaha keripik pisang senilai Rp. 85.110 dalam sekali produksi untuk 5 pemilik usaha keripik pisang.

Analisis R/C digunakan untuk mengetahui tingkat efesiensi keripik pisang secara finansial. Efesiensi home industry bisa ditentukan dengan menghitung per cost ratio yaitu pembagian antara penerimaan suatu usaha dengan total biaya produksi. 
Tabel 2. Analisis R/C Agroindustri

Keripik Pisang

\begin{tabular}{rlr}
\hline No & \multicolumn{1}{c}{ Biaya } & \multicolumn{1}{c}{ Jumlah } \\
\hline 1 & Penerimaan & $1,723,000$ \\
2 & Biaya Total & $1,673,890$ \\
3 & R/C & 1.03 \\
\hline
\end{tabular}

Diketahui pada tabel 8, bahwa penerimaan lebih besar dari biaya total sehingga nilai R/C lebih besar dari 1 yaitu 1,03 artinya dari setiap Rp.1.00 biaya yang dikeluarkan menghasilkan Rp.1,03 sehingga perajin memperoleh keuntungan Rp. 0,03 Dengan demikian agroindustri keripik pisang pada perajin keripik pisang di Desa Parigi Kecamatan Parigi Kabupaten Pangandaran menguntungkan bagi perajin.

\section{KESIMPULAN DAN SARAN}

\section{Kesimpulan}

Berdasarkan hasil dan pembahasan maka diperoleh beberapa kesimpulan sebagai berikut :

a. Besarnya biaya total pada perajin keripik pisang di Desa Parigi Kecamatan Parigi Kabupaten Pangandaran yaitu Rp. 1.673.890 persatu kali proses produksi, dan besarnya penerimaan Rp. 1.723.000 sehingga pendapatan yang diperoleh sebesar RP. 85.110. b. Besarnya $\mathrm{R} / \mathrm{C}$ yaitu 1,03 , artinya dari setiap Rp. 1.00 biaya yang dikeluarkan menghasilkan Rp. 1,03 sehingga pengrajin memperoleh keuntungan $\mathrm{Rp}$ 0,03. Dengan demikian agroindustri keripik pisang pada pengrajin keripik pisang di Desa Parigi Kecamatan Parigi Kabupaten Pangandaran menguntungkan bagi perajin.

\section{Saran}

Saran yang dapat dikemukakan adalah sebagai berikut :

a. Pengrajin harus lebih mengefisienkan biaya produksi yaitu biaya-biaya yang dikeluarkan dalam proses produksi.

b. Sebaiknya pengembangan pasar dilakukan dengan meningkatkan promosi dan dengan membuka pangsa pasar baru untuk mendapatkan pelanggan baru, terutama pelanggan di luar kota

\section{DAFTAR PUSTAKA}

Arikunto, S. 2006. Prosedur Penelitian Suatu Pendekatan Praktek. Rineka Cipta. Jakarta.

Suratiyah, K. 2006. Ilmu Usaha Tani. Penebar Swadaya. Jakarta.

_ , 2009. Ilmu Usaha Tani. Penebar Swadaya. Jakarta.

Daniel, MS. 2003. Metode Penelitian Sosial Ekonomi. PT. Bumi Aksara. Jakarta. 
Soekartawi, 2001. Pengantar Agroindustri. PT. Raja Grafindo Persada. Jakarta.

Desa Parigi, 2019. Monografi Desa Parigi. Parigi Pangandaran.

Dinas Perdagangan Koperasi \& UMKM Kabupaten Pangandaran, 2019. Data Agroindustri Keripik Di Kabupaten Pangandaran. Pangandaran.

Bappeda Jawa Barat. 2016. Penyusunan Rencana Kebutuhan Investasi Pusat Pertumbuhan Pangandaran Raya 2016. Bandung.

Palisuri, P. 2016. Analisis Produksi Dan Agroindustri Pisang Ambon Dalam Kaitannya Dengan Peningkatan Pendapatan Usahatani Di Kabupaten Gowa. Jurnal ecosystem, 16(1):1-12.

Nuryanti, Y., Rusman Yus, \& Sudrajat.2017. Analisis Biaya Pendapatan Dan R/C Agroindustri Keripik Pisang. Jurnal Ilmiah Mahasiswa Agroinfo Galuh Volume 4 Nomor 3 September 2017 :396-401.

Saleh, R. 2015. Analisis Pendapatan Keripik Pisang Pada Industri
Rumah Tangga Sofie Di Kota Palu. Jurnal Agrotekbis 3(5):680-654.

Angriani, U., Laapo Alimudin, \& Howara Dafina. 2014. Analisis Nilai Tambah Keripik Pisang Pada Industri Cahaya Indi Di Desa Tanamea Kecamatan Banawa Selatan Kabupaten Donggala. Jurnal Agroland 21(2):115-121.

Mokodongan, W., Mandei, \& Dumais. 2017. Nilai Tambah Keripik Pisang Pada Industri Rumah Tangga Ibu Dewi(Studi Kasus Kecamatan Malayang). Jurnal Agri-Sosial Ekonomi Unsrat Issn 1907-4298 Volume 13 Nomor 3a November 2017:27-32

Eviana Anita. 2017. Skripsi Analisis Keragaan Agroindustri Keripik Pisang. Skripsi

Salsabilla Shofia. 2018. Skripsi Analisis Pendapatan dan Nilai Tambah pada Agroindustri Keripik Pisang di Desa Sungai Langka Kecamatan Gedong Tataan Kabupaten Pesawaran. Skripsi. 